\title{
Comparative Image Analysis in Visual Arts and Art Education
}

\author{
Naciye Derin Isikoren ${ }^{1 *}$, Faruk Kalkan ${ }^{1}$ \\ ${ }^{1}$ European University of Lefke, N. CYPRUS
}

Received 19 June 2017 - Revised 15 September 2017 - Accepted 8 October 2017

\begin{abstract}
In visual art education, researchers has to be aware that it is necessary to explore the position of an image, within the time period's cultural, sociological, technological conditions that effect the image, in order to achieve a full understanding of that very image or visual composition. In that sense, setting a sample study that mirrors "how and under which effects a sign changes throughout time?" is worth investigating. The aim of this study is to explore the traces of symbolic existence of peripheral circumstances in a visual composition and as well as reflect that the composition is structured by these circumstances. In that sense, a brief review of the history of woman image has been chosen to set a sample study to search for the above mentioned dynamic. In order to trace the links in between meaning making and meaning reading processes, with the basic assumption that any sign's meaning differs according to its position among surrounding signs "woman image" offers continuity of existence throughout history which constitutes the bases for a comparative research. Continuity, in comparative analysis of an image may constitute a solid base in order to increase the level of cognation of students in the field of visual arts.
\end{abstract}

Keywords: art education, peripheral conditions, visual art, ideal, woman image

\section{INTRODUCTION}

The appearance of woman image throughout history cannot stand apart from a profound knowledge of that specific image's surrounding circumstances because woman image is shape shifting in accordance with its time period, geography, ideology and technology. Starting from the very early ages, there is a link between trade, social value, technology and woman image. The trade value of woman image is various as the image itself.

"Woman image" reflected by artists throughout time periods, stands as a suitable model for comparative analysis of the image itself and the time periods societal values, because it keeps its continuous existence in every era of the history of art. Therefore, it ensures a certain continuity in the comparison which is necessary for that research.

Continuous, yet variable existence of ideal woman image throughout different periods, offers the possibility of tracking the traces of symbolic existence of peripheral affects. Hence the symbolic existence of these motives formulates the image's variable nature, reflects the technological and social condition of that period in that image. In that sense, woman image, stands as a sample sign that addresses to the importance of exploring an image/sign with all its peripheral aspects, in order to compare the image and the period and find out the relativity.

The aim of this study is to explore the traces of symbolic existence of cultural and technological effects in an image and reflect that the composition is structured by these effects. In that sense, this study is a review of the history of woman image relative to that time period's societal and technological conditions and set its current position, in relation with art and culture education. Setting a sample study to reflect this relativity is the aim of this study. Art historian Gombrich, with his exquisite perspective emphasized the importance of analyzing the work or art within the context of societal and technological conditions "His range and depth of knowledge across a variety of disciplines gets marshaled for the much bigger enterprise of exposing inadequate theorizing about culture, and the way art is made and can be justifiably understood" (Cunliffe, 2015, p.28). 


\section{Contribution of this paper to the literature}

- During the analysis process

- Art students have to be aware of this dynamic and have to be able to observe the shape transition that occurs in the image, in relation with culture and technology.

- Comparative analysis on images has continuous existence in history constitutes a valid teaching material in order to investigate the question "how culture and technology affects a sign throughout time? Hence, the research will reflects the relation between art and culture and the relativity.

The analysis of woman images in history within the context of culture and technology of that period will reflect the links in between meaning making and meaning reading processes with the basic assumption that any sign's meaning differs according to its position among surrounding dynamics; "technologies are shaping how we live and interact (Roland, 2010), as well as extraordinary political and economic shifts in culture. New approaches to art education are required. Art education needs to move beyond previously defined disciplinary and theoretical boundaries toward broader, culturally relevant discourse" (Hausman, Ploof et all, 2010, p.370).

Analyzing and explaining a sign in art education has to abide to the awareness therapeutic meaning and position.

\section{METHODOLOGY}

The research conducted is qualitative in nature, structured as an analytical comparative articulation of the documentation of woman image in between time period of Paleolithic age, till 2000, within cultural, technological circumstances of the specific time period by taking the framing of Saussure's definition of language as a system of pure values which are determined by nothing except the momentary arrangements of its term. In artistic terms "The grammar of creative practices is described as the articulate organisation of perception, reflection and experience, the nerve structure of consciousness when it communicates with itself and with others. Steiner's description of creative grammar is consistent with Lev Vygotsky's comment that art is the social within us" (Cunliffe, 2011, p. 1). 


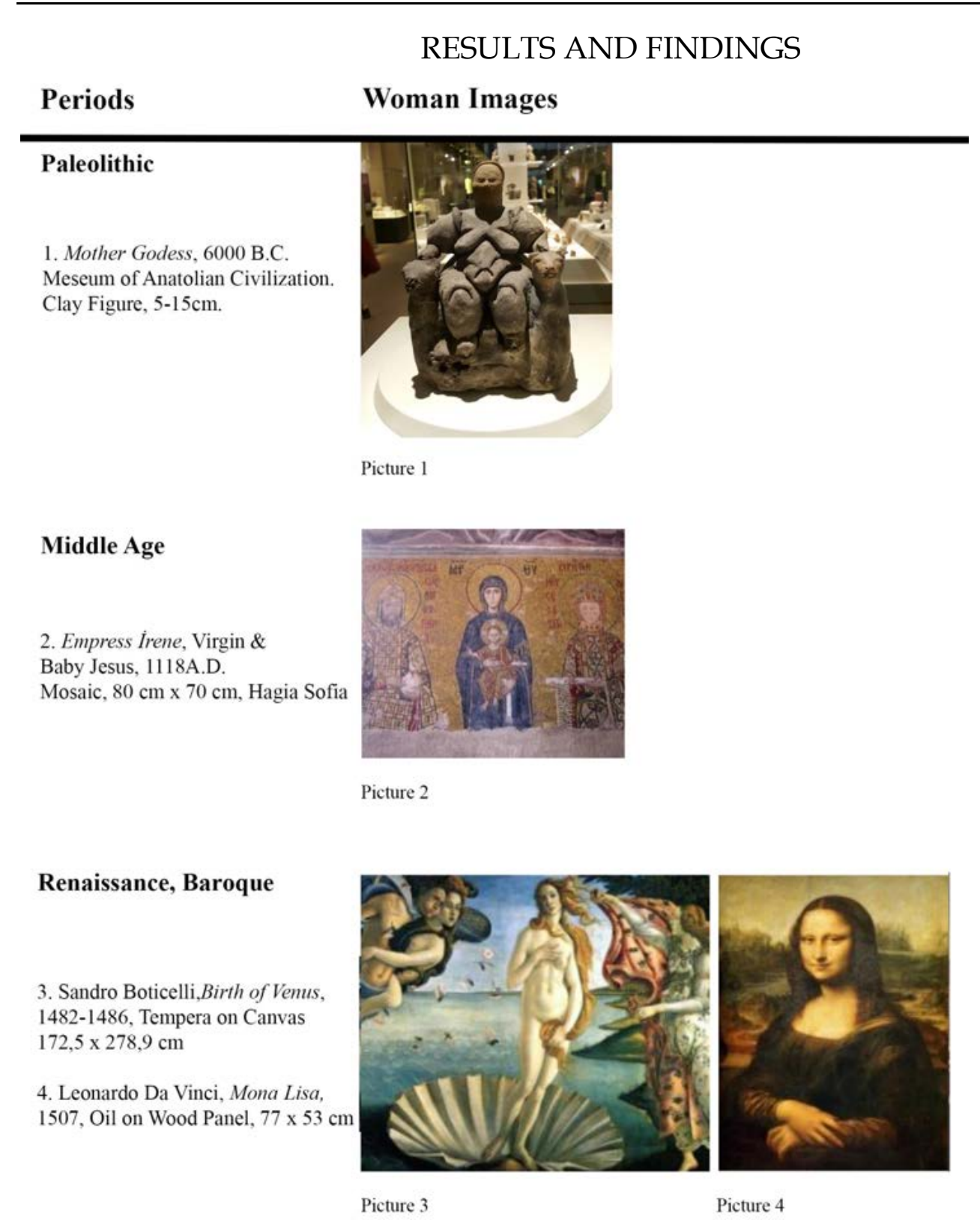

Figure 1. Woman Depictions Created in Between Paleolithic and Baroque Periods 


\section{Periods Woman Images}

Modernism
5. Pablo Picasso,
Demoiselles d'Avignon,
1907 , Oil on Canvas,
$244 \times 234 \mathrm{~cm}$.

Picture 5

6. Andy Warhol, Marilyn Monroe 1966, Silk Screen, $91,5 \times 91,5$

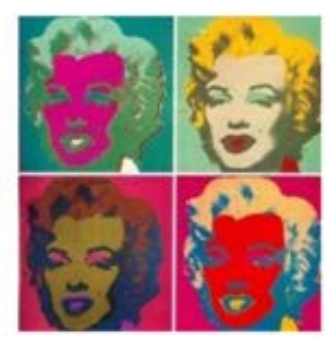

Picture 6

\section{Postmodern}

\section{\& Contemporary}

7. Herb Ritts, Stephanie, Cindy, Christy, Tatjana, Naomi, Hollywood, 1989, Silver Print

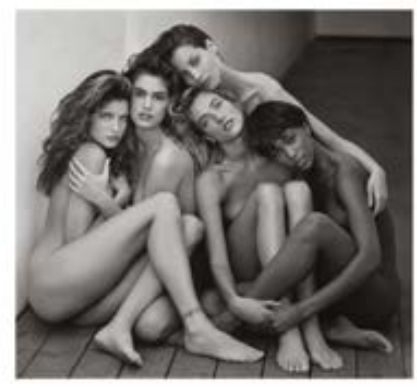

Picture 7
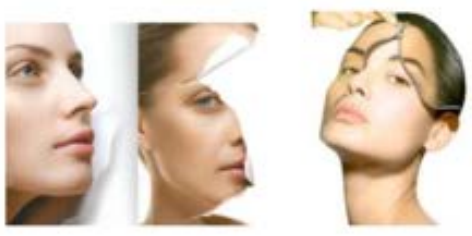

8. Vichy Advertising Campaign, 1990-2005

Picture 8

Figure 2. Woman Depictions Created in Between Modern and Postmodern Era 


\section{THE VALUE OF A UNIT IN THE PROCESS OF MEANING MAKING AND READING}

Saussure defines language as "a system of pure values which are determined by nothing except the momentary arrangements of its term" (Saussure, 1966, p.116). According to Saussure, it is possible to speak about a concrete unit only when the word is taken with its identity and value. Identity of a unit is not stable, it changes each time it is repeated in different sentences, it even changes with different inflections. In that sense the value of a unit becomes essential, a unit becomes concrete with its value. Value of a word or a term can exist only in accordance to its place within the linguistic structure. It is the existence of the other terms that defines the value of a word or a term. "Within the same language, all words used to express related ideas limit each other reciprocally...have value only through their opposition" (Saussure, 1966, p.117). In that sense it is the word's differences among others which determines its character, value and accordingly defines it as a unit.

A similar analysis system is valid for visual components. Signs, symbols, images are also defined as units or signifiers within visual language. Their meaning and value can only be defined with the other images that they are composed together and the pheripheral circumstances that surrounds them for that period of time and geographical position. In other words, "The dynamic and interactive concepts of history, heritage, tradition, and culture need to be defined from a social anthropological perspective to facilitate the understanding of art and visual culture education" (Ballenger, Stuhr, 2001, p.7)

It is important in visual arts to gain the perspective of looking to an image from various perspectives and understand that it does not only reflect what can be seen on the surface. Each image reflects its time periods cultural, technological and social conditions. Hence, as the image becomes a part of that culture, its value is assigned by that culture and society. Art researchers has to carry the avereness of this circular dynamic and art instructors has to enforce that avereness in order to create a grasp of the field. Within that understanding, this research is formulated as a sample study upon the changing woman image throughout time in order to set a clear and concrete example of the idea that mentioned above.

\section{WOMAN IMAGE AS A UNIT IN CULTURAL STRUCTURE}

The change in woman image and what this particular image means cannot be thought separate from its peripheral conditions. In that sense, the aim of this chapter is to emphasize that images are created by the artist and by the societal structure and technology of that society. At the same time, after the creation process, by entering into the cultural medium, the image itself affects society and technology. Therefore, it is necessary to analyze the image in terms of its composition and visual message, plus the analysis of the peripheral conditions should be brought forth. In order to understand the surface and under pinning of meanings, art researchers has to examine the constant change in art production. It would be futile to search for any kind of permanent reality of these images. Saussure's concept of value of the unit supports this idea. His semiotic theory, mentioned in this study is applicable to systems other than language.

Roland Barthes applies this theory into systems other than language and points out the issues of value and meaning in his study "Mythologies",

\footnotetext{
"The signifier and the signified, the former and the latter existed before uniting and forming the third object, which is the sign. It is as true to say that on the plane of existence, 1 cannot dissociate the roses from the message they carry, as to say that on the plane of analysis, 1 cannot confuse the roses as signifier and the roses as sign: the signifier is empty, the sign is full, it is a meaning" (Barthes, 1957, p.112). Signs are no different than a word in which the meaning is changing constantly according to its periphery of existence.
}

Umberto Eco points out to a similar concept in his book "History of Beauty" with these words, "Woman image as being a symbol of beauty has never been fixed; on the contrary, it is always changing in accordance with its time period, geography and other surrounding effects" (Eco, 2004, p. 14).

\section{SHAPE AND MEANING SHIFTS IN IDEAL WOMAN IMAGE}

Starting from the very early ages, there is a link between exchange, culture and woman image. The cultural value of woman image is various as the image itself. For example in the early ages, it was fertility, fruitfulness, increase of number.

Starting from Paleolithic period, woman images carried many different values and meanings that are expressing what is important in terms of value, according to her time and society that she belonged. Paleolithic figure of fertility or so called Venus figurines represented the need for survival, phrased in terms of fertility, reproduction and 
religious power (Gimbutas, 1989, p.3). A survival that includes fertility, as a previous and most important need for human being by representing women as feeder and breeder for next generations, which gives the main reason of humanity on earth.
"In old Europe, the focus of religion encompassed birth, nurturing, growth, death and regeneration, as well as crop cultivation and the raising of animals. The people of this era pondered untamed natural forces, as well as wild plant and animal cycles and they worships goddesses... The images of the goddess can be loosely categorized under her aspect of life giving and sustaining, death and renewal... It was the feminine force that pervaded existence (Gimbutas, 1989, p.3)"

Even the mythology proves the ever changing figure of women in society. The women imagery in ancient mythology represents the women figure as being nurturing i.e. Venus, in Roman religion and mythology, goddess of vegetation. Later, she became identified (3d cent. BC.) with the Greek Aphrodite. In imperial times she was worshiped as Venus Genetrix, mother of Aeneas; Venus Felix, the bringer of good fortune; Venus Victrix, bringer of victory; and Venus Verticordia, protector of feminine chastity. The most famous representations of Aphrodite or Venus in sculpture are the Venus of Milo or Melos (Louvre).

Then again in the same time period with the occurrence of Venus of Victrix, in between 520 and 420 BC, towards the end of fifth century, the attributed value of the goddess figures started to change as its proportions and craftsmanship. The religious functions of these figures were not the only point of interest anymore, the figures, sculptures started to gain value as art pieces. The enrichment of the variation in Greek art overlaps with the enrichment of society and the increasing number of different school of arts and styles, until Athens and Greece surrenders its prosperity to Sparta in 408 BC. (Gombrich, 1964, p.99-101).

In the early Christian era, with the change in the dominant religion (from Pagan to Christian), ideal woman image once again started to take a different shape. Venus was about to leave its place to the depictions of Madonna and Maria Magdalene, woman image would be a religious figure once again.

In $311 \mathrm{AD}$, Emperor Constantine established the Christian Church as a power in the State. That act changed the whole relationship with art, artist and the church because before that, creating legal places of worship was not possible but once it became legal and powered by the State, the situation has changed (Gombrich, 1964, p.134). Moreover, there was a great deal of emphasis in building and decorating churches in a different way than the Pagan Temples, to show the difference to the world and to the believers.

Pope Gregory stressed the educative role of paintings; they were carrying a great deal of importance in explaining religion to uneducated population. Plus Christians were not going to worship to the paintings or sculptures that were going to take place in Churches; they were going to worship to the holiness behind these depictions. After a lot of discussion opened by the Eastern Church Christian Iconography started to take its place in churches with some strict rules put by the church in the way of creation of the icons to be followed by the artist. As a result in between 900 AC and the Middle Ages the depictions of "Virgin and The Child" or "Madonna" took place of Venus as the new image value of woman.

Through the end of the Middle Ages a great deal of change emerged in the realm of art under the framing of Renaissance style and aesthetics which emerged from Italy in the first place.

\begin{abstract}
"In the early 1400s, the world woke up. From its beginnings in Florence, Italy, this Renaissance, or Rebirth, of culture spread to Rome and Venice, then, in 1500, to the rest of Europe (known as the Northern Renaissance): The Netherlands, Germany, France, Spain and England. The common elements were the rediscovery of the art and literature of Greece and Rome, the scientific study of the body and the natural world, and the intent to reproduce the forms of nature realistically" (Strichkland, 1992, p.32).
\end{abstract}

This particular stylistic change again was fostered by a series of surrounding historical affects such as when Gutenberg invented printing with movable type between the years of 1446-50, and with Medici's deposition in Florence, the art center shifted to Rome 1492, along with the discovery of perspective. In addition, Christopher Columbus landed in the Americas 1492.

The Renaissance spreads to Northern Europe during the years between 1500 and 1600 . At this time period, Martin Luther and the beginnings of Protestant Reformation in Europe 1517 began to ensue (Strickland, 1992, p.30). A great deal of new scopes and discoveries inscribed a definable concept of style and popular aesthetic perspective.

In the back stage of all these changes lies a perfect combination of circumstances such as

"for one thing, the conditions for artistic patronage were unusually favorable. Italy had developed
powerful city-state engaged in extensive trade and banking. The members of the merchant class, at the
head of this commerce, had a great deal of money to spend, were well educated, were highly motivated 
for reasons of prestige and temperament to invest in art. Also, the Christian Church was centered in Italy and it provided another important source of patronage" (Gilbert, 1998, p.395)

One of the reflections of Renaissance to art was the coming back of the Greco Roman motives and proportions to the painting and sculptor with a new interpretation of color scheme and perspective. As in the saying of Protagoras "Man is the measure of all things" (Strickland, 1992, p.12)

Woman image, within that scope changed again in the historical time line, Venus came back with its name, nudity, idealized beauty and mythology as it is possible to observe in Botticelli's The Birth of Venus, 1480. Venus was literally regenerated within a new cultural context.

After the Renaissance, during the Baroque and Rococo period 1600-1750, the rein of Church continued to shape the woman image. Though there was a limited liberation that came along with Renaissance, the subjects had to be still religious or mythological, limited to certain scales etc. Even during the time which is called "The age of kings" 17th and 18th century still there was this religious influence upon art realm. (Gombrich, 1964, p.325-342).

But in the following century, the church lost its ruling power. Industrialization and urbanization started to shape cities and effected cultural motives. The fast development of scientific and technological progress changed the shape of cultural values.

\title{
MODERN ERA
}

Unlike Renaissance and Baroque, 19th century faced 'isms' within shorter time periods, in comparison to previous art movements mentioned above. Until Realism and its manifesto put forward by Gustave Courbet (18191877), the art world and peripheral socio-cultural conditions were in interaction with political changes such as French revolution, the end of monarchies and newly established democracies. Especially Neo Classicism was in between the political chaos and academic forces of classical depictions. Romanticism reflected the humanistic outcome of this as escaping from all to faraway lands to find the real self- inside.

By the mid19th century, French artist and intellectual Gustave Courbet opened the doors of freedom for artists with a manifestation declared in his exhibition.

After the mid19th century, art freed itself from academic conventions and had boosted by decade long art movements. A good example for woman image during the era is Manet's Olympia, 1832-83.

Manet's Olympia is a different interpretation of women exchange value in society. At that time, artists used to use prostitutes as possible naked models for their portraits but that reality was not open in the image itself. For the first time, Olympia appears as an exchange object in society as being a prostitute, with a black servant who brings some flowers from her lover. With regard to that change in the value of the ideal woman image,

\begin{abstract}
"In modern art the category of the nude has become less important. Artists themselves began to question it. In this, as in many other respects, Manet represented a turning point. If one compares his Olympia with Titian's original, one sees a woman, cast in the traditional role, beginning to question that role, somewhat defiantly.

The ideal was broken, but there was little to replace it except the Realism of the prostitute- who became the quintessential women of early Avant-Garde 20th century painting. (Toulouse Lautrec, Picasso, Rouault, German expressionism etc.) In academic painting the tradition continued." (Berger, 1972, p.63-64)
\end{abstract}

Then again in the modern era, Picasso's women forms has influenced by primitive art but not in the sense of our ancestors who reflected women as being a fertility figure. Instead Picasso depicted woman image as a modern cultural exchange object.

With the invention of photography (1833) and steam powered rotary presses (1843), artists started not to reflect the photo realistic representations but a try to re-interpret the form itself. Especially with the manipulated photography, the open precertification and commoditization of the women image took its place and turned the woman image itself to an exchangeable product.

\section{SCIENTIFIC TOUCH TO THE WOMAN IMAGE}

After the industrial revolution, technology had a profound effect on the socio economic and cultural conditions of the time. The industrial revolution began in the United Kingdom and subsequently spread throughout Europe, North America, and eventually to the rest of the world. The use of wide spread technology speeded up all kind of production, transportation and consumption. Besides, the application of steam power to the industrial processes of printing supported a massive expansion of newspaper and popular book publishing, which caused the mass 
production and mass distribution of all kind of image and reproduction of art works. As a result work of art lost its aura and uniqueness.

"Art works became one of the trade goods themselves. Popular culture and popular art started show its face to the world" (Hobbs, Duncan, 1992, p.486).

Along the road, another reason for image making occurred as a part and need of that day's necessities and that was advertising. As the economy expanded during the 19th century, advertising grew alongside. At the turn of the century, there were few career choices for women in business and advertising was one of the few. Since women were responsible for most of the purchasing done in their household, advertisers and agencies recognized the value of women's insight during the creative process. In fact, the first American advertising to use a sexual sell was for a soap product. That was one of the turning points of woman image, starting from that time woman image would be an indispensible part of commerce and most mass produced image of all times, this time, not because of its religious or academic value, but rather as a sex object, an object of desire.

\section{CONTEMPORARY WOMAN IMAGE AND ADVERTISING}

After the modern era, in contemporary culture, sexuality in woman image came forward in direct or indirect ways. Technologically fostered media, as an active arm of capitalist economy, has objectified woman image as an object of desire. This objectification brought a need of perfection of the woman image as it has never been that exaggerated before. In $1980 \mathrm{~s}$, the image of perfect looking woman settled in everyday life with the strong use of science and technology, it was not only a media or fashion image anymore. Woman, herself had to be perfect looking in order to take her place in daily life. In other terms, the image of perfect woman was stuck in the woman herself.

\footnotetext{
"In the consumer package, there is one object finer, more precious and more dazzling than any other-and even more laden with connotations than the automobile, in spite of the fact that that encapsulates them all. That object is the BODY. Its 'rediscovery', in a spirit of physical and sexual liberation, after a millennial age of Puritanism; its omnipresence (specifically the omnipresence of the female body, a fact we shall have to try to explain) in advertising, fashion and mass culture; the hygienic, dietetic, therapeutic cult which surrounds it, the obsession with youth, elegance, virility/femininity, treatments and regimes, and the sacrificial practices attaching to it all bear witness to the fact that the body has today become an object of salvation. It has literally taken over that moral and ideological function from the soul. (Baudrillard, 1970, p.129)
}

Mass media, advertising and medical technologies, created a repeated insistence of beauty standards for woman who are not as beautiful or thin as the models that has been used in the adversary images. That insistence, from the economy scope is also an insistence of a life time consumption of certain dietary and cosmetic products, as a direct attempt of maintaining growth in that industry and a direct attempt profit making.

Following the constitution of the contemporary woman image and the reflection of that image to everyday practices, a new development occurred in the scientific platform.

This new development was like the answer to woman's need in her struggle of looking perfect. In July of 1990, The New England Journal of Medicine published an article by Daniel Rudman stating that "the effects of six months of human growth hormone (hGH) on lean body mass and adipose tissue were equivalent in magnitude to the changes incurred during 10 to 20 years of ageing" (Rudman, 1990).

That was the first tangible and very promising result of the new field in medicine called "Anti-aging". The field later on would bring the science person touch as a peripheral affect to the formulation of contemporary woman image.

Anti-aging movement is consisted of implementations which, claims to make individuals live longer and healthier by controlling their bodily conditions and lifestyle choices. Anti-aging movement has boomed after 1990's. From its inception, anti-aging has been mentioned with the words such as medicine, cure, industry, solution, formulation, therapy, cosmetics, hormone, vitamin, pill, drug, prescriptions, diet, exercise, test, technique etc.

Another development that occurred in 1990 gave way to a quick spread to the idea of anti- ageing and that was the use of internet.

All these developments also gave way to a "culture of perfectibility" which has a scientific basis as mentioned in Mykytyn's study (Mykytyn, 2010, p.185)

Meanwhile, popular media discovered the field around 1995 and loved the idea and its potential in advertising. There were a huge amount of products and services related to the field and the field was medical, correspondingly legit. The money spent for anti-ageing by the consumers became billion dollars per year within five years. 
The economical promises of the field, its popularity in the media and the production of numberless related goods and services made the idea of anti-ageing a very valuable advertising concept.

With the use of the concept of anti-aging, woman image does not reflect fertility, spirituality or mythology (as it was in the historical line) anymore, it rather reflects a certain fixity, operationally, control which shows a parallelism to the aim of enlightenment. The aim of enlightenment in Adorno and Horkheimer's description was "liberation of man from fear and establishment of their sovereignty" (Adorno \& Horkheimer, 1976, p.8-15), dominance over nature.

\section{CONCLUSION}

Woman images in different time periods has been compared to each other both structurally and contextually in order to set a sample model that reflects the idea that any sign, image shape shifts among peripheral effects that it surrounded with and gain value, meaning within that position. Within that scope, this study has documented the change in woman image in various time periods depending on that time period's social, cultural and technological changing power dynamics, starting from Palaeolithic age, till 2000.

In Palaeolithic period, the value and meaning of woman image was fertility, fruitfulness and population growth. During the middle age, with the change in the belief system, the meaning of the image shifted and became an icon of the Christian church and gained value with biblical discourse. Renaissance and reform movements reshaped woman representations with Greco roman motives and proportions, hence nudity returned in a more detailed way to the ideal image. After the mid19th century, woman image freed itself from academic conventions and religious iconic values. Instead, woman image became a modern cultural exchange object. Finally, the contemporary value and shape of woman image reflects a state of fixity, sterilization and control which shows a parallelism to the aim of enlightenment and scientific developments which fosters the technology that enable the manipulation of the woman image itself.

Consequent to the lack of coherency in the shape and composition of the woman image, both in terms of representation and value, it is possible to mention that in visual art studies, sign's, symbol's, image's meaning has to be explored according to its position among the time periods societal, cultural and technological conditions. All visual production has purposes that have direct links to its peripheral effects.

In that sense, comparative analysis in visual art education upon symbols, images, encloses structural and narrative composite components of that very image and its relative value changes as a sign.

\section{REFERENCES}

Barthes, R. (1957). Mythologies. Seuil, Paris: Paladin.

Barthes, R. (2013). Elements of semiology. New york: Hill and Wang.

Baudrillard, J. (1970). La socie te de consommation: ses mythes, ses structures (SGPP, Paris); translated in 1998 as The Consumer Society: Myths and Structures.Ballengee-Morris and C. Ballengee-Morris, C., \& Stuhr, P. L. (2001). Multicultural art and visual cultural education in a changing World. Art Education, 54(4), 6-13.

Berger, J. (2008). Ways of seeing (Vol. 1). UK: Penguin.

Cunliffe, L. (2011). Creative grammar and art education. The Journal of Aesthetic Education, 45(3), 1-14.

Cunliffe, L. (2015). Wittgenstein's and Gombrich's parallel therapeutic projects and art education. The Journal of Aesthetic Education, 49(1), 20-35. doi:10.5406/jaesteduc.49.1.0020

De Saussure, F. (2011). Course in general linguistics. New York: Columbia University Press.

Eco, U. (2004). Storia della Belleza. Milano: Bompiani.

Everts Mykytyn, C. (2010). A history of the future: the emergence of contemporary anti-ageing medicine. Sociology of health \& illness, 32(2), 181-196.

Gilbert, R. (1998). Living With Art. Ohio: Mc Graw Hill.

Gimbutas, M. (1989). The Language of the Goddess. London: Thames and Hudson.

Gimbutas, M. (2001). The Living Goddess. London: Paperback

Gombrich, E. H. (1964). The Story of Art. London: Phaidon

Hausman, J., Ploof, J., Duignan, J., Brown, W. K., \& Hostert, N. (2010). The condition of art education: Critical visual art education [CVAE] club, Winter 2010. Studies in Art Education, 51(4), 368-374. Horkheimer, M. \& Adorno, T. (1976) Dialectics of Enlightenment, Paperback Edition

Hobbs, J. A., \& Duncan, R. L. (1991). Arts, Ideas and Civilization. New Jersey: Prentice Hall. 
Parambi, T., Prabhakar, V., Ravikumar, K. G. (2010), The Hopes and Hypes of Anti Aging Technologies-The Quest for the Elixir of Youth. Journal of Pharmacy Research, 3(4), 725-731.

Peppin, P., \& Carty, E. (2001). Semiotics, stereotypes, and women's health: Signifying inequality in drug advertising. Can. J. Women $\mathcal{E}$ L., 13, 326.

Roland, C. (2010). Preparing art teachers to teach in a new digital landscape. Art Education, 63(1), 17-24.

Rudman, D., Feller, A. G., Nagraj, H. S., Gergans, G. A., Lalitha, P. Y., Goldberg, A. F., ... \& Mattson, D. E. (1990). Effects of human growth hormone in men over 60 years old. $N$ Engl J Med, 1990(323), 1-6. doi:10.1056/NEJM199007053230101

Shields, V. R., \& Heinecken, D. (2002). Measuring Up: How advertising affects self-image. Philadelphia: University of Pennsylvania Press

Strickland, C. (1992). The Annotated Mona Lisa. Kansas City: A Universal Press Syndicate Company.

\section{http://www.ejmste.com}

